\title{
Barriers to Developing Competition in the Polish Electricity and Gas Market
}

\author{
Sylwia Słupik ${ }^{1}$ \\ ${ }^{1}$ Department of Social and Economic Policy, Faculty of Economics, University of Economics in Katowice, \\ Katowice, Poland \\ Correspondence: Sylwia Słupik, Assistant Professor, Department of Social and Economic Policy, University of \\ Economics in Katowice, 1 Maja 50 St. 40-287 Katowice, Poland. Tel: 48-32-257-7565. E-mail: \\ sylwia.slupik@ue.katowice.pl
}

\author{
Received: April 30, $2012 \quad$ Accepted: May 31, $2012 \quad$ Online Published: July 20, 2012 \\ doi:10.5539/ibr.v5n8p160 URL: http://dx.doi.org/10.5539/ibr.v5n8p160
}

\begin{abstract}
The paper presents main barriers of creating a competitive energy market in Poland. Polish energy and gas sector in space of few recent years underwent breakthrough changes as far as regulations, structure, organisation and ownership are concerned. Drivers of change included the necessity to align national regulations with EU standards through transposition, and creating entities strong enough to finance their own investment outlays. As a result of those changes, both private and public producers and providers can compete for customers whilst using the regulated network infrastructure. Through those changes regulatory bodies were established and some of the following measures were used: TPA rule, accounting unbundling, legal unbundling and functional unbundling, merger \& acquisition supervision on the national and regional level, state aid programmes and a range of other instruments facilitating consumer access to competitive power purchase offers concerning energy and natural gas. However, electricity and gas markets still remain dominated by market incumbents plus the competition is still limited, particularly so in the natural gas market. Among barriers impeding development of Polish energy sector and liberalisation of electricity and gas markets are: vertical consolidation in the sector; wrong architecture of the wholesale market; unstable regulatory environment; maintaining retail prices for households regulated; low consumer activity in the energy market.
\end{abstract}

Keywords: Poland, electricity market, gas market, liberalisation, main barriers

\section{Introducation}

The energy sector is centrepiece to development of every contemporary country. Its sustainable development is crucial to guarantee national energy security. Key component of that development is keeping electricity supplies at a safe level meeting nationwide demand, providing energy at competitive prices and in line with current legislation, including environmental regulations and social expectations. Current energy situation worldwide requires adaptive measures to adjust legislation, because long-term forecasts are not conclusive as to prospective difficulties with finding new sources of energy. Energy resources, especially threat of short supply of resources, could be used as an instrument influencing international relations. The highly competitive electricity and gas markets pose a challenge to assure safety of energy supplies both short-term and long-term. Conditions required to meet that objective is to secure adequately high and well-structured energy investments. Under normal circumstances, those investments are subject to lengthy administrative procedures and are capital intensive. That means the market cannot respond to signals issued by its participants as that reaction is usually sluggish and ultimately late. Investment and pro-growth energy policy are fundamental as they guarantee safety of energy supplies, rational energy generation costs and compliance with ecological requirements.

Polish energy and gas sector in space of few recent years underwent breakthrough changes as far as regulations, structure, organisation and ownership are concerned. Drivers of change included the necessity to align national regulations with EU standards through transposition, and creating entities strong enough to finance their own investment outlays. In accordance with EU law all member states are obliged to implement into national legislation provisions of the 3rd energy package, which came into force on March 3rd 2011. The process of implementing EU regulations has not been concluded, however, once it comes into full effect, the new legislation will facilitate integration of the energy market and will speed up sluggish rate of development restraining 
competition in Polish electricity and gas market.

This is essential as there are numerous challenges in front of the Polish market. The necessity of fundamental and far-reaching modernisation tied in with increasing capacities converges with inevitable adapting measures to comply with costly requirements stipulated by the European Climate Package. Poland is obliged to limit its $\mathrm{O}_{2}$ emissions and switch to low energy economy at the same time. High energy demand, inadequate generating, fuel transport and energy infrastructure, substantial dependence on external natural gas supplies and as near as makes no difference complete dependence on external petroleum supplies as well as environment protection obligations - including climate related - require taking decisive actions to outset the threat of fuel and energy consumers being worse off.

Well-oiled and healthy markets are absolutely key to assure safety of supplies and improve efficacy and quality of services. Over recent few years, Poland has made inroads into liberalising its electricity and natural gas markets. Liberalisation, however, is a continuous process and as it was in case of other countries, there is loads yet to be done before a fully robust market emerges from the process. Electricity and gas markets still remain dominated by market incumbents plus the competition is still limited, particularly so in the natural gas market.

\section{Characteristics of the Polish Energy Sector}

In 1990 Poland entered the arduous transition process of shifting from centrally planned economy to market economy. The energy sector managed to carry out considerable social, political and economic reforms. As a result of dropping industrial output and growing GDP energy consumption fell. This was particularly evident in demand for electricity and coal due to closures of energy-intensive heavy industry facilities. Among the most important changes which took place over that period in Polish energy sector are (European Investment Bank, 2008):

$\checkmark$ "rationalisation" of energy consumption aimed at decreasing already high energy consumption in Poland and increasing efficiency of the energy sector, improving quality of produced coal, reducing heat waste etc. It involved starting the energy saving process which is yet to be concluded both from supply and demand point of view,

$\checkmark$ reform of energy pricing strategies aimed at restoring the link between prices and market conditions which often ends up with higher energy prices,

$\checkmark$ restructuring reform involving transforming vast, ineffective enterprises into separate companies.

The energy sector is one of the fastest developing parts of the economy. Growing world population, economic growth and giant technological leap over recent years are all factors fostering increasing energy demand. Poland owns some of the biggest coal deposits in Europe, hence it became the mineral of choice for the energy generating industry. In 2011 86\% of Polish primary energy supply came from fossil fuels, whereas the remaining part was provided by biomass and biogas. While the dominance of coal in national fuel consumption has significantly loosen its grip - $76 \%$ in 1990 down to $56 \%$ in 2008 , the aggregate reliance on fossil fuels has decreased only by $5 \%$ over the same period from $98 \%$ to $93 \%$ due to increasing importance of petroleum and natural gas (OECD/IEA, 2011).

Use of coal as key fuel, on one hand makes Poland independent of foreign energy supplies, on the other though, it may generate additional costs and decrease competitiveness of this fuel among other energy sources. Tight link between the power and coal industries creates the danger of electricity sector becoming vulnerable to economic and social hardship experienced by the mining industry. This is observed through pressures on increasing and "regulating" prices to the power industry for coal and fuel deliveries.

Historically, petroleum has been the second most important fuel and its consumption has nearly doubled since 1990 by reaching $25 \%$ in 2009 . Also noteworthy is maintaining for few years now increasing production of renewable energy. Consumption of gas and biomass grew by $4 \%$ over past three decades by reaching $13 \%$ and $6 \%$ respectively in 2008. It should be emphasized that other power stations have also increased their output thus underlining shooting up importance of distributed generation (in 2009 30\% increase year-on-year) (Energy Regulatory Office, 2011a).

The processes taking place in Polish energy market in 2010 characterised with growing output and consumption of electricity. In 2010 national demand for electricity was $154.98 \mathrm{TWh}$ which translates to $5.5 \%$ increase compared to 2006. The same year Polish commercial and utility power stations generated a total of $157 \mathrm{TWh}$ of energy. That is $21 \%$ more the Ministry of Economy forecasted (Ministry of Economy, 2009).

According to PSE Operator SA reports national electricity consumption increased in 2010 4\% year-on-year, 
whilst energy output grew over the same period by $3.59 \%$. Note, this comparison concerns 2009 - the year of economic downturn.

Table 1. Domestic production of consumption of electricity (TWh) according to PSE Operator SA

\begin{tabular}{|c|c|c|c|}
\hline & 2010 & 2009 & $2010 / 2009$ \\
\hline TOTAL OUTPUT & 156337 & 150912 & $3.59 \%$ \\
\hline Commercial power stations: & 146104 & 141874 & $2.98 \%$ \\
\hline Water power stations & 3266 & 2751 & $18.72 \%$ \\
\hline Thermal power stations & 142835 & 139120 & $2.67 \%$ \\
\hline - $\quad$ black coal fired & 89208 & 84272 & $5.86 \%$ \\
\hline - $\quad$ brown coal fired & 49459 & 50796 & $-2.63 \%$ \\
\hline _ $\quad$ Gas-fired power stations & 4164 & 4049 & $2.84 \%$ \\
\hline Other renewables & 10 & 21 & $-53.81 \%$ \\
\hline Wind farms & 1298 & 820 & $58.29 \%$ \\
\hline Utility power stations & 8923 & 8203 & $8.78 \%$ \\
\hline National energy consumption & 154983 & 148721 & $4.21 \%$ \\
\hline
\end{tabular}

Source: PSE Operator SA.

Renewables consumption in Polish energy sector increased according to 2010 data. Output of run-of-the-river power stations increased by almost $18 \%$ whilst wind farms' by $58 \%$. Output level has also increased at biomass and biogas fired power stations. Furthermore, renewables are gaining ground on a regular basis, what finds reflection in generating capacity dynamics. Compared to year before, by year-end 2010 renewable energy plant had $19 \%$ more operational generating capacities. Consequently renewables-based energy output increased as fraction of total energy output from 5.8\% in 2009 to $6.2 \%$ in 2010 (Grant Thornton Frackowiak, 2010). Higher renewable energy production is stimulated by putting in place certain mechanisms. There are two fundamental systems supporting renewables investment in force in Europe. First - feed in tariff, practised in majority of EU Member States. Polish Energy Law (Energy Law, 1997) act imposes on electricity distributors requirement to buy from their suppliers a predetermined quotas of renewable energy. The system of so called colour certificates is a vital factor supporting renewable energy production. However, despite it being in place already since 2005 , fraction of renewables in total energy output in Poland remains still inconsiderable. In 2010 it reached as much as $6.8 \%$. This means that despite renewables consumption increased by $26 \%$, set out by the Ministry of Economy target of $7.5 \%$ renewables fraction in total national energy output was not met (Minister of Economy, 2010). Note that European Union requires Poland to produce $15.5 \%$ of its total energy output from renewables by 2020 .

Dynamic fast-paced boost in production of renewable energy was caused above all by wind energy. Power output from renewables increased in 2010 by almost half. Wind energy production also did strengthen thereby confirming the long-term upward trend for consumption of this type energy. Wind energy has growing stake in total renewable energy output which grew during 2010 from 13\% to over $15 \%$.

Another renewable energy source which plays an increasingly important role in the Polish energy sector is biomass. Polish investors tend to put greater resources behind biomass-based projects (either biomass combustion or co-firing with coal) aimed at generating electricity and thermal energy. Investment in biomass-fired power station is planned by both major energy conglomerates (i.a. Tauron, DGF, SUEZ or Dalkia Poland) and local cogeneration plants. Polish energy policy forecasts increasing consumption of that energy particularly as far as biogas is concerned. In accordance with Ministry of Economy estimates, biogas fraction in total renewable energy output will shoot up over next 20 years from $4 \%$ to $17 \%$ and will provide $11 \%$ of total heat energy compared to current $1 \%$. Those forecasts are confirmed by data from the Energy Regulatory Office. They show that generating capacity of biomass-fired plants increased in Q1 of 2011 by 42.86 MW to 399.05 MW i.e. by over 12\% (Grant Thornton Frackowiak, 2010).

Total consumption of natural gas in 2010 in Poland was 158.1 TWh. 110.4 TWh/year of imported gas was complemented by nationally extracted gas i.e. $46.3 \mathrm{TWh} /$ year which covered approx. $30 \%$ of domestic natural gas demand. Compared to 2009 , total gas consumption soared by $7.8 \%$, imports by $9 \%$ whereas domestic extraction sprung by just $2.7 \%$ at constant generating capacities. Total gas imports in 2010 featured gas from Russia, Ukraine and intra-Community supplies from Germany and Czech Republic. The highest share of gas imports was provided by Russia as part of agreement concluded in 1996 between PGNiG SA and Gazprom Export. Under that contract $99 \mathrm{TWh}$ of natural gas was purchased translating to $89 \%$ of total gas imports into 
Poland, whereas transit of fuel gas fed through Polish part of the Yamal-Europe pipeline was $259.41 \mathrm{TWh} /$ year. The remaining demand was satisfied with supplies from Germany, Ukraine and Czech Republic. Total volume of gas supplies provided under provisions of gas import agreements was 1038 million $\mathrm{m}^{3}$, which equalled approx. $11 \%$ of total gas imports to the Polish territory. In 2010 only two entities purchased gas for further resale. It was a relatively small amount - just over 18 thousand tonnes of liquefied natural gas, bought without using the TPA rules (Energy Regulatory Office, 2011b).

Table 2. Gas supplies in 2010

\begin{tabular}{ll}
\hline Item & Quantity [million $\left.\mathbf{~ m}^{3}\right]$ \\
\hline $\begin{array}{l}\text { Imports, including: } \\
\quad \quad \text { Yamal LNG agreement }\end{array}$ & $\mathbf{1 0 0 6 6 . 4}$ \\
\hline Intra-Community purchase/Country of origin & 9028.4 \\
a. Czech Republic & \\
b. Germany & 0.3 \\
\hline Other imports/Country of origin & 1031.9 \\
a. Ukraine & 5.9 \\
\hline Domestic extraction & 4220.4 \\
Gas reserves (change in reserves) & 272.1 \\
\hline
\end{tabular}

Source: PGNiG SA.

\section{Companies and Concentration of the Electricity Market}

Over recent years Poland has made inroads into liberalisation of energy markets through implementing EU regulations concerning liberalisation of energy markets and supplies security faster than other EU Member States where transition processes had already taken place. Despite positive transformations, however, Polish electricity and gas market still shows little competitiveness.

Current composition of the energy sector and concentration of their operations are effect of horizontal consolidation processes followed by vertical M\&As of companies owned by State Treasury. Both the electricity production sector and the wholesale market remain under strong concentration. The industry leader as far as generation is concerned is PGE Capital Group SA. The sector of energy providers is dominated by Tauron Group SA. The consolidation process which in fact has not concluded, will have had major impact on opportunities for building a competitive wholesale marketplace. The lion's share of generated electricity $(90 \%)$ is sold under bilateral agreements. Fraction of energy sold in the spot market (stock exchange, electricity trading platforms) remains low in spite of increases observed in 2009. Sheer dominance of bilateral agreements and capital group concentrated trade have their impact on suppressing wholesale market liquidity and causes the pricing policies to remain murky. An open and robust wholesale market would be key to have real competition (OECD/IEA, 2011).

In 2010 the sales structure at the wholesale market looked similar to previous years. The main electricity consumers at the energy wholesale market were energy distributors. Sales were generally made between capital group companies. Polish Power Exchange (TGE SA) showed fast-paced growth dynamics in 2010. Main reason for increasing energy sales through exchange were amending provisions to the Energy Law act coming into force by August 9th 2010. They obligated all energy producers to sell through the stock exchange either $15 \%$ or $100 \%$ of their generated output (concerning producers qualifying for the long-term contract programme). Volume of trade at the Polish Power Exchange reached 3 TWh a mere 2\% of total electricity consumption in 2009. Nonetheless that was a $45 \%$ increase year-on-year. Further $4.36 \mathrm{TWh}$, i.e. $2.93 \%$ of domestic electricity consumption was sold through On-line Electricity Trading Platform. Due to growing trading volumes at TGE SA, Polish energy market is liquid enough to give third party access to interconnection with the Scandinavian market through market coupling mechanisms i.e. implicit auctions made at power exchanges: Nordpool Spot and TGE SA. The cross-border transmission capacity of monopolar high-voltage direct current (HVDC) submarine cable between Poland and Sweden (SwePol Link) is 600 MW. This high voltage cable enables members of TGE and Scandinavian NordPool Spot Exchange to sell generated energy to other markets and purchase cheaper energy from neighbouring markets. The main issue, however, in the way of full integration between Polish and neighbouring markets are insufficient cross-border transmission capacities (Energy Regulatory Office, 2011b).

The Polish retail electricity customer market is shaped by 16 million end-consumers, $85 \%$ of which are households. Electricity sold to households makes up for approximately $24 \%$ of total electricity sold. Polish 
transmission grid is maintained by state-owned PSE Operator SA supervised by the Ministry of Economy. Apart from end-consumers, participants of the retail market are distribution system operators (DSO) and electricity providers (energy trading companies). The biggest sellers of electricity are incumbent companies, which emerged after separating out distribution system operators (currently seven entities) as parties to comprehensive agreements i.e. agreements combining provisions of purchase-sale agreement and power purchase agreement concluded with consumers. They operate in capacity of ex officio distributors for households, which did not make the decision to switch suppliers. Apart from the big seven there are also other providers (approximately twenty active members), whose origins do not trace back to old distribution companies. There are also approx. 200 other vertically integrated industrial electricity suppliers which apart from selling also offer distribution services. The number of entities holding electricity distribution licences totals approx. 300 companies (Energy Regulatory Office, 2011b).

Bearing in mind the majority of distribution system operators are incorporated into groups owning both production and supply units, the process of becoming downright and fully independent is a slow one, however, all formal and legal obligations concerning DSO independence have been fulfilled. The division responsible for supplies in each of the groups, sells energy mainly to consumers connected to distribution network owned by that group. Energy Regulatory Office stresses DSOs achieved a significant milestone in 2009, whereby they worked out equal terms for all users of the system and equal access to distribution networks for third parties. The competition beyond operating area of DSOs increases gradually at a slow pace though due to closely matched competitive offers (OECD/IEA, 2011).

Initiated in 1998 liberalisation process of Polish electricity sector entered the stage when fully competition-promoting measures were in place by July 1st 2007, when in accordance with EU directives consumers were empowered to choose electricity suppliers. Consumer activity on Polish electricity market measured by number of customers switching suppliers remains low. In 2009, over 1060 local clients (located within operating area of given supplier) changed suppliers. In 2008 that same number was 905, and in $2007-541$. Fraction of connected external customers (measured by energy consumption) was significantly lower than of households. Increasing compared to previous years number of companies switching providers in 2009 was linked to economic downturn which pressured businesses to cut costs thus find better energy offers. In 2008 the administrative procedure of switching providers was shortened and simplified. Regardless of that improvement, other barriers of different character were still in the way. There still are not enough competitive offers what explains low interest among consumers. As far as residential customers are concerned, the state of affairs is down to tariff regulations concerning households, which show little differentiation between suppliers. According to Energy Regulatory Office, among other barriers is "lengthy process of concluding power purchase agreements and unfavourable provisions putting consumers at a disadvantage once they decided to switch providers". Moreover, knowledge on possibility and procedures for switching suppliers is deficient, especially among households putting additional constrain on competition.

Table 3. Consumers switching providers in 2006-2009

\begin{tabular}{lllll}
\hline \multirow{2}{*}{ Year } & \multicolumn{2}{l}{ Consumers switching providers by energy consumption (\%) } & Number of renegotiated \\
\cline { 2 - 5 } & $\begin{array}{l}\text { Large industrial } \\
\text { consumers }\end{array}$ & $\begin{array}{l}\text { Average industrial and commercial } \\
\text { consumers }\end{array}$ & $\begin{array}{l}\text { Small business and individual } \\
\text { consumers }\end{array}$ & \begin{tabular}{l} 
agreements \\
\hline 2006
\end{tabular} 15.84 \\
\hline 2007 & 16.95 & 0.012 & 0 & 47 \\
\hline 2008 & 15.95 & 0.128 & 0.001 & 44 \\
\hline 2009 & 22.39 & 0.309 & 0.005 & No data \\
\hline
\end{tabular}

Note: ${ }^{*}$ renegotiation of agreement is synonymous with amending agreement with previous supplier.

Source: Energy Regulatory Office.

However, despite the number of consumers who took advantage of their right to switch suppliers in 2010 remains low, it nevertheless is an increase on 2009 figures. Study factoring in different tariff groups, proves that in 2010 the number of consumers who decided to change their energy provider grew in excess of $300 \%$ compared to 2009. In tariff groups A, B, C (commercial consumers) that number was approx. $500 \%$ and in tariff group $\mathrm{G}$ (individual consumers) - approx. $17 \%$. When evaluating those indicators, however, one should bear in mind that very few consumers (mere $0.05 \%$ of all consumers) have already taken advantage of their right to switch. 


\section{Companies and Concentration of the Gas Market}

Natural gas is one of key energy resources. Poland consumes just shy of 14 billion $\mathrm{m}^{3}$ of natural gas per annum. Most of it comes from a single dominating supplier (PGNiG SA) which in turn buys the resource from Russian Federation. This state of affairs will probably not change in forthcoming several years. Polish gas market in its current shape does not promote intensive competition, nonetheless one of most important sources of competitive advantage is access to natural gas sources (Buczkowski, 2009). PGNiG (72.5\% owned by State Treasury, 12.7\% owned by eligible employees, the remaining shares are free float) is the market leader both in terms of upstream and downstream sectors. It is virtually an exclusive gas importer - entitlement to $100 \%$ of transmission capacity of all entry points. Moreover, by being the biggest gas extraction company ( $98 \%$ of domestic output), PGNiG is calling the shots in the natural gas wholesale market. Gas trading companies outside the PGNiG Capital Group have no stake in gas wholesaling (OECD/IEA, 2011).

In 2010 gas was traded still under provisions of bilateral agreements. Thus far gas has not been sold in Poland through stock exchanges or hubs.

Apart from PGNiG Capital Group there are approx. 30 independent entities operating on the Polish market dealing with distribution and sales of gas. How dynamically they develop is contingent on formalising the process of designing and building gas networks. Technical capabilities of existing transmission infrastructure and its development also play an important role.

Part of market reform in the Polish gas sector was separating out in terms of ownership operations linked to transmission of natural gas, which originally were governed by PGNiG. In 2004 a new state unit was formed as part of PGNiG - completely independent transmission system operator OGP GAZ-SYSTEM SA, which went on to become state controlled in 2005. In June 2007 six distribution companies were legally disassociated from PGNiG, which were granted by Energy Regulatory Office status of a distribution company. They remain a hundred percent owned by PGNiG.

The fact which substantially influenced the landscape of Polish natural gas market, including managing and operating gas transmission, was delegating Gaz-System SA to become the operator of Polish part of the Yamal-Europe Transit Gas Pipeline System (TGPS). By decision of the Energy Regulatory Office President of November 17th 2010, that company was appointed gas transmission system operator for Polish part of the Yamal- Western Europe pipeline until December 31st 2015 (Energy Regulatory Office, 2011b).

High saturation in Polish gas market caused by dominant position of PGNiG Capital Group has taken its toll for many years on the structure of retail market and its transition rate. Still $98 \%$ of natural gas is sold by the monopolist, whereas the remaining $2 \%$ represents several dozen entities, which aspire to develop and strengthen their market position (G.EN Gaz Energia, CP Energia, EWE Polska, Enesta SA and KRI S.A.). Best part of those companies sells gas through own local distribution networks. Exception here is EWE Polska, which also imports natural gas from West through its own network using the EU transmission system. In 2009 is imported from Germany approx. 35.65 million $\mathrm{m}^{3}$ of natural gas under agreement with EWE AG.

The TPA rule in force since June 1st 2007, which counteracts discriminatory practices toward third party access to network thus gives right to freely choose and switch gas supplier, remains redundant as in practice the switching rights are not exercised. Providers independent of PGNiG - due to low commercial quantities - are not obligated to give third party access to their distribution networks, even though from the legal standpoint the consumer is entitled to switch supplier twice a year free of charge. Moreover, PGNiG is the sole proprietor and operator of the storage system as ruled by the Regulator in 2008 for the period of 17 years. In 2010 PGNiG owned $100 \%$ of underground gas storage capacities. The company provided in 2010 for Gaz-System SA 50 million $\mathrm{m}^{3}$ of gas due to the enterprise acting in capacity of transmission system operator. The remaining storage capacity was used entirely for purposes of PGNiG SA operations.

In 2010 active capacity of underground gas storage was approx. 17.9 TWh.

In accordance with art. 24 of Act on Reserves of crude oil, petroleum products and natural gas and procedures applying to situations threatening domestic energy security and oil market disruptions (Journal of Laws No. 53 item 343, 2007) companies importing gas fuel into Poland are obligated to maintain minimum reserves and keep them available throughout Polish territory by using storage installations connected with Polish transmission system. Due to storage capacity deficit and barred access to storage services, imposing the requirement on entities importing gas to hold reserves of gas fuel effectively denied them the opportunity to enter the market of new suppliers, thus hampering its development (Buczkowski, 2009). 
Table 4. Polish underground gas storage in 2010

\begin{tabular}{lllll}
\hline No & Storage name & Type of storage & Active capacity [million $\mathbf{~ m}^{3}$ ] & Reading by the end of reporting period [million $\mathbf{~}^{3}$ ] \\
\hline 1 & Wierzchowice & mature gas field & 575.00 & 386.564 \\
2 & Brzeznica & mature gas field & 65.00 & 41.153 \\
3 & Strachocina & mature gas field & 150.00 & 98.964 \\
4 & Swarzow & mature gas field & 90.00 & 49.521 \\
5 & Husow & mature gas field & 350.00 & 270.313 \\
6 & Mogilno & salt caverns & 370.00 & 302.308 \\
7 & Daszewo & mature gas field & 30.00 & 8.825 \\
8 & Bonikowo & mature gas field & 200.00 & 47.371 \\
TOTAL & & $\mathbf{1 8 3 7 . 8 9 0}$ & $\mathbf{8 7 7 . 2 0 3}$ \\
\hline
\end{tabular}

Source: PGNiG SA

\section{Liberalisation of Electricity and Gas Sector Objectives}

Polish energy policy is determined by EU directives and requirements to a great extent. Poland has to liberalise its natural gas and electricity market in particular by implementing competition mechanisms. Not only will a competitive marketplace stimulate improvement of operational efficiency and cost-optimising measures on the supply side, but also more efficient energy consumption and deployment on the demand side. This will be achieved through incentivising economic signals. Developing a competitive market environment is one of objectives set out by Polish Energy Policy until 2030 (Ministry of Economy, 2009). PEP 2030 and its Executive Actions Programme for 2009-2012 envisages a range of short-term measures intended to increase competition in electricity and natural gas markets. According to that document, liberalisation aims to assure undisrupted energy market and thus counteract excessive price rises.

Among specific objectives are:

1) Lifting barriers obstructing supplier switching.

2) Developing competition mechanisms as the main measure rationalising energy prices.

3) Regulating naturally monopolised markets in best interest of all market participants.

4) Limiting red tape in areas where competitive markets operate and develop.

5) Co-building regional gas and electricity market with international trade being the main focus.

6) Implementing and effective electricity balancing mechanism increasing energy supplies security, supporting futures and intraday trading, and facilitating identification and allocation of individual costs of energy supplies.

7) Creating a liquid spot market and futures market.

Objectives of Polish energy markets liberalisation comply with target objectives of European energy policy competitiveness, sustainable development and energy security.

Table 5 shows a matrix of specific objectives for liberalisation of electricity markets, from both short-term and long-term perspective.

Liberalisation of the energy market entails predominantly measures within the framework of energy policy. They concern introducing and extending competition mechanisms deployed in liquid fuels, natural gas and coal markets. Poland, as EU member state actively contributes in creating joint Community energy policy, and also delivers on its main objectives in specific domestic environment. In doing so, consumer interests need to be protected, whilst keeping strong grip on current energy reserves as well as technological consideration regarding energy production and transmission.

One of key objectives of Community's energy policy is creating an internal, EU-wide electricity market after other commodity markets in order to enable free flow of goods (energy) and services (transmission, distribution). The process of creating EU-compliant energy market depends above all on rebuilding structurally the energy industry. That in turn involves disjoining electricity production and trading from transmission and distribution, putting TPA rules into practice, deregulation of wholesale and retail prices, counteracting further consolidation (horizontal in particular), modernising energy infrastructure, and passing adequate legislation. Furthermore, for the first time, already at the stage of developing energy sector and building administratively electricity market, consumer interest is actually on the list of priorities for the changes. Hence it is fair to say that together with 
pro-competitive rules for electricity market being put in place, companies operating in the energy sector are going to - similarly to common practice - become increasingly customer-centric i.e. striving to explore customer needs and catering for them. This will be a departure from current situation where best consumer interest is neglected (Office of Competition and Consumer Protection, 2011).

Table 5. Specific objectives of Polish electricity market liberalisation

\begin{tabular}{|c|c|c|}
\hline Item & Short-term perspective & Long-term perspective \\
\hline Technical & $\begin{array}{l}\text { maintaining proper operating condition } \\
\text { of generating, transmission and } \\
\text { distribution infrastructure and devices }\end{array}$ & $\begin{array}{ll}\checkmark & \text { replacement and development investments in generation and } \\
& \text { transmission/distribution, } \\
\checkmark & \text { new generation technologies, } \\
\checkmark & \text { improvement of generating and transmission efficiency, } \\
\checkmark & \text { expanding cross-border networks and connections } \\
\end{array}$ \\
\hline Economic & $\begin{array}{l}\checkmark \quad \text { energy price covers energy generation } \\
\text { and provision costs } \\
\checkmark \quad \text { good organisation of energy trading } \\
\text { which would not hamper market } \\
\text { access (i.a. unjustified participation } \\
\text { fees) } \\
\text { effective system protecting against } \\
\text { anti-competitive practices and abusing } \\
\text { market leader position by sector } \\
\text { members }\end{array}$ & $\begin{array}{l}\checkmark \quad \text { energy price covers investment outlays, enables developing } \\
\text { market mechanisms favourable for electricity sales at prices } \\
\text { justified by current energy prices and distribution costs, } \\
\text { discarding the "socialisation" cost } \\
\checkmark \quad \text { effective system protecting against anti-competitive } \\
\text { practices and abusing market leader position by sector } \\
\text { members }\end{array}$ \\
\hline $\begin{array}{l}\text { Economic } \\
\text { and Social }\end{array}$ & $\begin{array}{ll}\checkmark & \text { protection of vulnerable consumers, ex } \\
& \text { officio providers (backup), social } \\
& \text { programmes } \\
\checkmark & \text { ex-ante periodic price control } \\
\checkmark & \text { consumer protection against unfair } \\
& \text { practices of energy providers and } \\
& \text { distributors } \\
\checkmark & \text { promotion of energy saving }\end{array}$ & $\begin{array}{ll}\checkmark & \text { systemic protection of socially vulnerable indifferent to } \\
\checkmark & \text { competition mechanisms } \\
\checkmark & \text { efficient energy consumption } \\
\checkmark & \text { economic growth at sustainable energy consumption }\end{array}$ \\
\hline
\end{tabular}

Source: Roadmap of price deregulation for all electricity consumers "Towards consumer tights and efficient competition in energy sector". Energy Regulatory Office, Warsaw 2008, p. 17.

The objective declared key for energy sector reform, has been and remains increasing efficiency of the energy sector predominantly through competition. Hence expected are fall in electricity prices, better service quality, assuring comparative energy prices in member states, consumer right to switch provider and boosting activity in the sector which eventually would reduce needs concerning building and maintaining generating and transmission capacities. Changes in the Polish electricity market have to be aimed at giving birth to fundamentally strong enterprises, which would be capable of assuring sustainable energetic development. The overarching objective for ushering in the reforms should be national energy security, achieved through investment increasing generating, transmission and distribution capacities underpinned by reliable supplies. Transitions in the market should decrease costs and harmonise the energy sector. Cost minimisation as objective of energy policy will bring about better efficiency of energy companies, which should be stimulated by favourable regulatory policy. Consolidation will generate economies of scale and synergies within the market causing energy production costs to drop. As a result of those measures Polish companies will have become more competitive in the integrating international electricity market and our energy sector will actively participate in developing the international electricity commerce.

Another objective of Polish Energy Policy until 2030 is also injecting competitiveness into gas markets. Liberalisation of natural gas market - dictated by EU directives - will have diminished the importance of coal. This will enable market mechanisms to shape the structure of domestic energy market, allowing in turn natural gas prices to be more competitive and consequently improving energy security of Poland.

\section{Barriers to Developing a Competitive Energy Market in Poland}

The process of creating a competitive energy market in Poland has been in progress for 10 years now. There were spells of fast tracking and regress, where accelerating and decelerating factors have blended together. In the process, changed were monopolistic structures holding a strong grip over extracting, processing and providing 
energy into diversified businesses (state-controlled to a variable extent) with extensive portfolios and operating under different forms of ownership. As a result of those changes, both private and public producers and providers can compete for customers whilst using the regulated network infrastructure. Through those changes regulatory bodies were established and some of the following measures were used: TPA rule, accounting unbundling, legal unbundling and functional unbundling, merger \& acquisition supervision on the national and regional level, state aid programmes and a range of other instruments facilitating consumer access to competitive power purchase offers concerning energy and natural gas (Swora, 2010).

History of Polish electricity market reforms and implementing competition mechanisms into the electricity market, proves it was inconsistent and unsuccessful. It is the end-consumer who bears the cost of incomplete programmes, forsaken measures or measures not followed through correctly, lengthening of the legislation process (especially in terms of implementing European legal provisions).

The act - Energy Law, passed in 1997 was to some extent a summary of transitions in the energy sector, which took place over the course of profound reforms after changing the Polish economic-political system, and introducing an independent regulatory body. At the same time, however, a regulatory mechanism was introduced based on so called reasonable costs, and the amount of long-term contracts concluded between producers and an operator as the single buyer did literally explode. Establishing an energy stock exchange and introducing the balancing market both in 1999 was beyond doubt a pro-market solution. Over the course of that evolution, however, consistency was missing - the energy stock market in Poland thus far remains marginalised. At the next stage of market development, whilst implementing the so called II liberalisation package, distribution system operators were legally unbundled and transmission system operator functionally unbundled. Termination of long-term agreements was also due in that period. This was supposed to increase competition in the sector. On the other hand, that period was dictated by vertical consolidation as result of which four entities were formed vertically integrated groups incorporating companies dominating the market (Swora, 2010). Lack of competition resulting from closing energy trade within consolidated groups, causes fundamental problems with accounting for state aid, which was intended to compensate producers - parties of KDT - for losses incurred due to their participation in the market.

As far as legislation is concerned, among key positive changes which took place in 2010 are:

1) Passing extensive amendment to the act - Energy Law, which apart from regulations implementing the directive concerning safety, includes also provisions introducing obligation to participate actively in stock exchange trading, applicable to producers granted state aid due to KDT termination.

2) Appointing the Ministry of Economy the new corporate supervisor of the PSE Operator company instead of the previous Ministry of Treasury, consequently strengthening unbundling (separating commerce from distribution, transmission and storing services) of transmission system operator.

3) Change in pricing policies for co-generated heat, based on reference prices.

Creating pro-competition conditions fostering its development is set out as strategic objective both in Polish Energy Policy as well as the act Energy Law. In 2010, however, actions put in place fell short of the goal. Although EU provisions were implemented, at the same time rigorous legislation was put in force which had negative impact on existing companies and effectively barred new entities from entering the market.

Polish Confederation of Private Employers Lewiatan (Polish Confederation of Private Employers Lewiatan, 2011) points toward key barriers impeding development of Polish energy sector and liberalisation of electricity and gas markets. Among those barriers are:

1) Authors of the report list the following regulatory barriers concerning the electricity market:

$\checkmark$ not transparent legislative process,

$\checkmark$ no reliable ex ante / ex post analyses and studies into deliverables of regulatory changes,

$\checkmark$ no schedule of introducing changes into Polish Law to aligned it with EU legal changes,

$\checkmark \quad$ unstable regulatory environment, which poses a threat to successful execution of investment projects in the generation sector. Such unfavourable circumstances could not even be offset by high electricity prices thus discouraging for undertaking investments,

$\checkmark$ regulatory risk influencing decisions of transmission and distribution system operators e.g. ERO President's ruling on power purchase prices compensating grid losses, causing operators to incur massive financial losses considerably decreasing their investment capabilities, 
$\checkmark$ convoluted legislation inconsistent with executive acts, difficult to interpret and use, additionally causing extra risk factor to market strategies of energy companies,

$\checkmark$ independence and discretion of regulator's decisions.

2) In terms of barriers concerning legal forms and ownership of energy companies the following were listed:

$\checkmark$ vertical consolidation in the sector - increased market power of some entities, decreased the number of wholesalers and caused energy to be generated and sold predominantly within consolidated groups - this was detrimental to transparency of market conditions and prices. In practice this caused an oligopoly to form.

$\checkmark$ low transparency of the wholesale electricity market, slowing down investments due to low investor confidence,

$\checkmark \quad$ withheld privatisation of the energy sector resulting in low energy and economic efficiency of the sector as well as reduced investment capabilities,

$\checkmark$ monopolistic practices in the balancing energy market caused by vertical consolidation of the energy sector,

$\checkmark$ wrong architecture of the wholesale market,

$\checkmark$ flawed model of offsetting costs incurred by the operator through balancing market operations through transmission tariffs forcing operators to apply measures reducing that cost - with mixed success for balancing market participants.

3) Barriers in the retail energy market:

$\checkmark$ maintaining retail prices for households regulated,

$\checkmark$ low consumer activity in the energy market,

$\checkmark$ incorrect implementation of EU directive concerning supplier of last resort,

$\checkmark$ unclear regulation concerning duties of and choosing "reserve supplier" and/or "emergency supplier",

$\checkmark$ inconsistent rules on switching energy suppliers by consumers (including customers of energy companies without the status of distribution system operator),

$\checkmark$ obligation upon consumers to adapt their meters when switching energy supplier to other than local trading company.

Moreover, among main barriers impeding creation of competitive electricity market report authors listed undue compensations for stranded costs, discriminative prices for companies outside consolidated groups, incomplete cost restructuring within energy groups and excessive fiscalism of State Treasury which have had its reflection in energy price rise caused by insufficient competition in the wholesale market. Fiscal and parasifcal charges built into energy prices are $25 \%$ and $50 \%$ for industrial consumer and household respectively. Excise for electricity is five to ten times higher than minimum rates in the EU. Complicated procedures of settling excise for trading companies and consumers cause impose additional charges on energy consumers. Another vital matter still hanging in the air is building cross-border connections. Hence, in the medium-term Poland will not be able to participate in the Integrated Energy Market, which will take its toll on Polish energy security and will restrain new suppliers from coming into the market, thus having negative impact on competition. Another issue raised by report authors is unjustified subsidising amortised renewable energy sources (big hydroelectric plants). Through that practice, the green producers increase their profit at cost of all energy consumers - without having to increase their renewable energy production (Polish Confederation of Private Employers Lewiatan, 2011).

Current shape of the gas market has been inherited after long-standing single-supplier market where the monopolist called the shots. Technical and price barriers to entry for new entities were also contributing factors. One of fundamental barriers to creating a competitive energy market is the regulatory policy, where PGNiG calculates the tariffs effectively obtaining undervalued gas price. PGNiG throws costs of imported gas and domestically produced gas together into one basket. Maintaining the price basket for PGNiG is unfavourable for competition in domestic market. Companies showing possible interest in providing Poland with gas, remark that entering the market are virtually impossible, because the new market actor would not be able to offer comparable prices. Bearing in mind decommissioning the PGNiG price basket would above all increase prices for the end-consumer, it should not be expected the regulator would take that decision anytime soon (Buczkowski, 2009).

One of key barriers to developing the gas market in Poland is restricted access to natural gas resources for new entrants (PGNiG claims practically the entire imported natural gas plus on top of that it remains the largest gas 
producer in Poland). Limited access to underground gas storage is another barrier to developing competition within the sector. PGNiG is the sole proprietor and designated operator of underground storage capacities and practically the only user at that. What is missing are clear and effective rules assuring equality in access to storage capacities for all market actors, which should be rigorously pursued. An independent storage system operator could be the best solution to provide non-discriminatory third-party access to storage capacities.

Another factor holding back potential competition from entering the market are stringent rules on maintaining particular gas reserves. Another obvious step in direction of competitive gas market is improving connections with neighbouring countries. Today's gas transmission system in Poland is still relatively isolated from other countries. It enables only unidirectional flow (East-West). Gas Transmission Operator GAZ-SYSTEM SA, however, plans to implement a range of investment projects in 2009-2014 which are aimed to change that. Long-term agreement between PGNiG and Gazprom as well as no third party access to the Yamal pipeline are also a considerable hurdle in way of developing competition (OECD/IEA, 2011).

To summarise, current barriers to entry for new wholesale gas suppliers and developing competition are:

$\checkmark$ no inter-system connections,

$\checkmark$ no storage infrastructure,

$\checkmark$ gas price in domestic market dictated by the "price basket", which disenables reflecting the true market value of gas,

$\checkmark$ rigid rules on calculating tariffs making impossible to have flexible and competitive client approach.

\section{Conclusions}

A competitive marketplace is the driving force behind any market economy. One of key conditions underlying competition is favourable market structure. It cannot be excessively concentrated. In case of monopolization and stiff competition it is difficult to talk about real competition.

In Poland, liberalisation is more advanced in the electricity sector. Both the production and wholesale sector remain under fierce competition. The forward-moving vertical consolidation of the energy sector produced situation where there is a limited number of energy groups enjoying strong market power. The Polish electricity market could be described as illiquid. Among key factors capable of influencing that, is large fraction of bilateral contracts, and despite having made notable progress still insignificant fraction of stock exchange transactions. The new regulations ordering producers to trade $5 \%$ of generated electricity either on energy stock exchange or the regulated market are supposed to increase competition in the wholesale sector. That legislation was critical to the wholesale electricity market and higher liquidity of the Polish wholesale market enabled implementation of market coupling mechanisms through the monopolar high-voltage direct current (HVDC) submarine cable between Poland and Sweden.

Although the Polish electricity market opened its doors to retail competition as of June 1st 2007, the right to switch energy provider remains - in accordance with EU Directives - limited. This is above all due to no alternative, attractive offers for households, justified to some extent by regulated tariffs set on comparable levels.

The energy market is undergoing continuing restructuring and privatisation. Electricity and gas markets have been dominated by market incumbents for years what restrained competition, in the gas market in particular, which is one of the markets showing little competition and high concentration. Restructuring of the gas sector is under way - including establishing structures stipulated by the second EU liberalisation package i.e. independent and state-owned transmission system operator and six distribution system operators. In spite of these efforts, the gas market remains still strongly monopolised. PGNiG SA goes on to maintain its dominant position both in upstream and downstream sectors. By being the sole domestic gas importer and producer it effectively controls the wholesale market. PGNiG is also the dominant force in the retail market. Market share of all the other companies operating in the sector is a mere $2 \%$. This "incumbent structure" creates situation where measures aimed at promoting and increasing competition meet with far more hurdles than in the electricity sector.

Restrained competition in the Polish energy sector is unfavourable for improving operational efficiency of energy companies and causes too heavy of a burden for end-consumers. Track record of market reforms in form of $81 \mathrm{TWh}$ of electricity sold on the stock market compared to production of $157 \mathrm{TWh}$, just under 9 thousand consumers switching their provider out of 16.5 entitled prove that effects delivered by the changes are unsatisfactory. Balance of costs and benefits could and should provoke reflections. This state of affairs is yet to be affected by discussions over investment crisis, reproduction and development needs as well as the climate package - solving those problems could not harm efforts aimed at bringing about efficient competition. It would 
be hard to come by something better than a competitive market to trust it with creating a rationally operating economy.

\section{References}

Buczkowski, M. (2009). Factors influencing competition in the Polish gas market. Professional Gas Industry, strony, 68-69.

Energy Law. (April 10, 1997).

Energy Regulatory Office. (2011a). Report of the President of Energy Regulatory Office. Warsaw: Energy Regulatory Office.

Energy Regulatory Office. (2011b). National Report of the President of the Energy Regulatory Office 2011. Retrieved http://www.ure.gov.pl/portal/pl/424/4258/Raport_Krajowy_2011_Prezesa_URE_dla_Komisji_Europejskiej .html

European Investment Bank. (2008). Gas market study for Poland by 2035. Final report. European Investment Bank.

Grant Thornton Frackowiak. (2010). Polish energy market. Summary 2010. Retrieved from http://grantthornton.pl/images/raporty/Raport_Rynek\%20energetyczny_w_Polsce.pdf

Minister of Economy. (2010). National Action Plan for renewable energy. Warsaw: Minister of Economy.

Ministry of Economy. (2009a). Polish Energy Policy until 2030. Warsaw: Ministry of Economy.

Ministry of Economy. (2009b). Projection of demand for fuels and energy until 2030. Warsaw: Ministry of Economy.

OECD/IEA. (2011). Energy Policy of MAE countries. Poland 2011. Review. OECD/IEA.

Office of Competition and Consumer Protection. (2011). Consumer on the electricity market. Warsaw-Wroclaw: Office of Competition and Consumer Protection .

Polish Confederation of Private Employers Lewiatan. (2011). Barriers in the energy sector. Warsaw: Polish Confederation of Private Employers Lewiatan.

Swora, M. (2010). Poland in the process of integrating EU member state markets. Eneregy Market, I(V). 